\title{
No 'Thing to Wear': A Brief History of Kimono and Inappropriation from Japonisme to Kimono Protests
}

\author{
MICHELLE LIU CARRIGER
}

\begin{abstract}
In June 2015, a small strange protest erupted in the Boston Museum of Fine Arts, around a sumptuous red kimono, provided to visitors to try on and emulate the 1876 painting La Japonaise, by Claude Monet. Protesters named themselves Decolonize Our Museums and took to the gallery and social media with strident messages condemning the Kimono Wednesdays try-on activity as racist, orientalist appropriation; soon after, counterprotesters faced off, defending the programme for sharing Japanese culture with the community. In this article, I consider the kimono protests as part of a history of kimono, internationally created yet indelibly marked as Japanese. In this context, the kimono protests provide an occasion to consider the ramifications of contemporary debates about cultural appropriation and appreciation. Through a performancetheory inflected analysis I propose a theatrical ethic of 'inappropriation' as a means of moving discourse and public performances of culture beyond the stultifying binaries of right/wrong or appreciation/appropriation.
\end{abstract}

Gallery 208, the Museum of Fine Arts (MFA), Boston. In this room hangs Claude Monet's 1876 painting La Japonaise. Contrary to its title, there is no Japanese woman in it: the painting depicts Camille Monet, the painter's wife, wearing a sumptuous kimono. She's twisted toward the viewer/portraitist in a classic feminine pose, cribbed from the Japanese ukiyo-e prints so popular in France at that moment, holding up a Japanese-style folding fan in blue, white and red (the colours of the French tricolour flag) in front of a backdrop featuring many more Japanese fans. The gallery guide informs us that the 'naturally dark-haired' Camille is also wearing a blonde wig, 'to emphasize her Western identity'. In effect, the painting reflects the height of Japonisme in nineteenth-century France, so excessively that some critics claim it was meant as a parody of the French obsession with Japan. ${ }^{1}$ Turned in two directions, Camille faces back toward the future viewer, or the former artist, poised at the apex of a craze, smiling with equanimity at both her husband, the artist who will later disavow his work as une saleté ('a piece of filth') and at generations of gallery visitors. By summer 2015, Camille's painted image was smiling down at an unruly crowd some of whom were precisely copying her pose and affect in a replica of her red kimono, while others were vigorously denouncing the painting, the re-enactors and the museum that housed them all. ${ }^{2}$ 
La Japonaise's latest controversy began on 24 June 2015, the first night of the MFA's summer programme, Kimono Wednesdays. Visitors on open-late, pay-what-you-can Wednesdays were invited to try on replicas of the kimono Camille wears in $\mathrm{La}$ Japonaise and listen to a short gallery talk entitled 'Claude Monet: Flirting with the Exotic'. In addition to patrons trying on the heavily embroidered and padded kimono and posing for pictures, three protesters stationed themselves in the gallery, holding hand-lettered signs made of plain printer paper with messages about orientalism, exotification and racism. That first Kimono Wednesday coincided with the retirement festivities of the museum director, Malcolm Rogers, who, when asked by a Boston Globe reporter about the protesters, declared, 'a little controversy never did any harm'.

Over the next two weeks, however, the protesters named themselves 'Stand against Yellowface' in a Tumblr account and Facebook page (changed a couple of weeks later to 'Decolonize Our Museums', which they frequently abbreviated to 'DOM'), publicized a 'list of charges and demands' and chosen hashtags, and began garnering significant media attention, especially in the realms of Asian American activism, art criticism and Boston-area and Japanese-centric news. Having initially refused Stand against Yellowface's demand that they stop allowing visitors to try on the kimono, the MFA capitulated, although they continued displaying the kimono for visitors to touch and examine for the remainder of the programme's scheduled six weeks. By week three, as the numbers of protesters crept up (only three the first week, then five, then a dozen and later up to twenty or so), counterprotesters also began to appear: mostly older, mostly Japanese and Japanese American, and many wearing kimono (see Fig. 1). ${ }^{5}$ Two camps emerged: DOM protesters told reporters that the MFA was 'perpetuating Orientalism. They don't give any context. They're like, try this on, and that's it. That's not the way to do it'. ${ }^{6}$ The MFA insisted, 'We don't think this is racist', in a memo apparently intended only for staff. ${ }^{7}$ Counterprotesters concurred with the museum, presenting signs with messages such as, 'I welcome museum exhibits that share Japanese culture with the community', head to head with DOM signs bearing messages such as, 'THIS IS RACIST. THIS IS APPROPRIATION. THIS IS ORIENTALISM'. Jiro Usui, the deputy consul general of Japan, in Boston told the Boston Globe, 'We actually do not quite understand what their point of protest is. We tried to listen to those people who are protesting, but we think together with the MFA we should encourage that Japanese culture be appreciated in a positive way'.

The plot thickened yet again with the revelation that the MFA's two replica kimono had actually been donated to the museum by NHK, the Japanese national broadcasting company, after they had been made and used for an identical dress-up programme in Japan during La Japonaise's tour of art museums there during 2014-15 as part of an exhibition called 'Looking East: Western Artists and the Allure of Japan'. NHK's kimono, one larger and one more child-size, had been painstakingly constructed by the costume shop of the Takarazuka all-women musical revue company in Kyoto, the traditional centre of kimono design and manufacture. ${ }^{9}$ While the painting was on display at the Nagoya Art Museum, fans and even a blonde wig were provided for guests to try on along with the kimono. Special souvenir toys and stationery of 


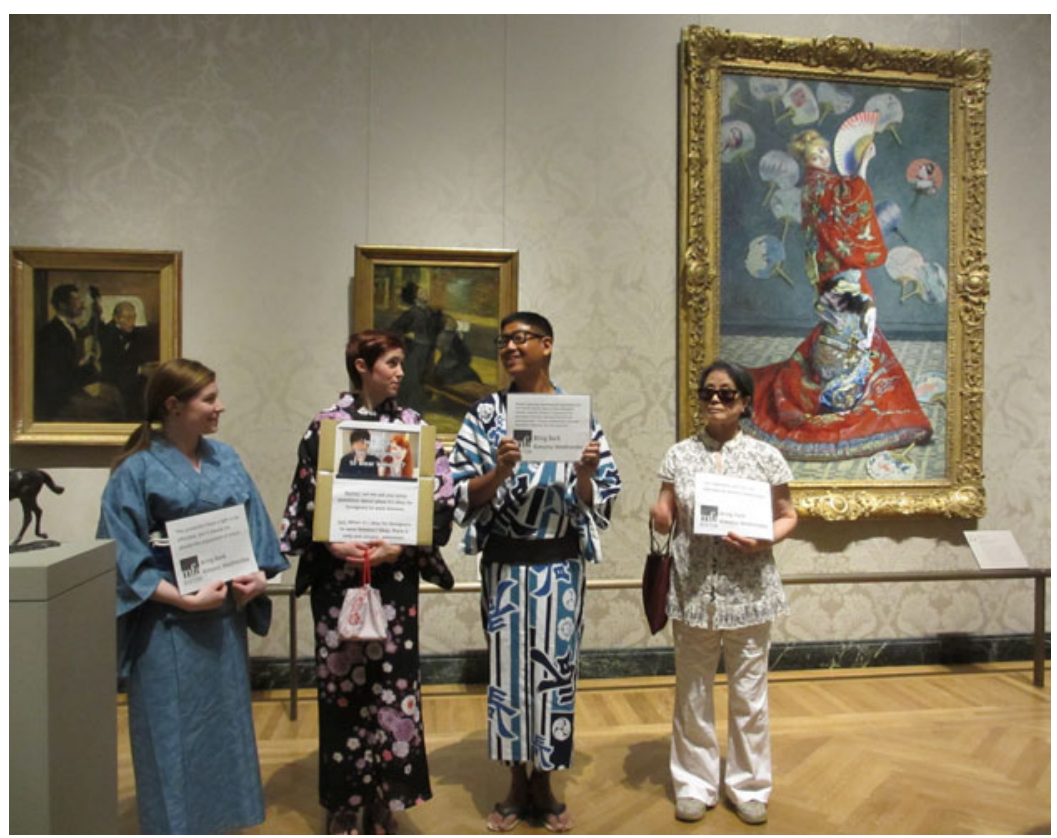

FIG. 1 (Colour online) Counterprotesters (left to right: Ashley Lehane, Ara Mahar, Timothy Nagaoka, Ikuko Burns) in front of La Japonaise on 15 July 2015. Photograph by Keiko Kawabe.

cartoon bear mascot Rilakkuma as La Japonaise were released. Somehow, however, in its transoceanic return to Boston, La Japonaise picked up wild new stakes and the gift of kabuki kimono made by the women's revue company became the star of an entirely new drama.

I was riveted by the kimono protests from the moment I heard about them after the first or second event. Like many of the counterprotesters, I have spent a lot of time wearing kimono in Boston as a student of Japanese tea (and as a clothing enthusiast). Although I am not of Japanese descent, I lived in Japan for three years, in two different stints; from 2012-13 I spent one year in a tea-training programme in Kyoto where I wore kimono as a sort of school uniform every weekday and many weekends. And yet, like many of the protesters, I identify as Asian American, and moreover I am accustomed to being on the side of the protest for cultural sensitivity and against the institution. Finally, as a performance scholar and theorist with research specialities in both Japan and clothing, I thought that performance studies ought to have something to add to the debate around the kimono protests. After all, no one had protested the display of La Japonaise in the museum; it seemed to be the activity of physically trying on the kimono that protesters identified as fundamentally different, as orientalist, racist appropriation. The introduction of replica kimono and the try-on activity appeared to reactivate the orientalist heritage that had lain dormant in the museum all along. I wondered whether there was significance to the 
act - the performance - of putting oneself in the orientalist frame? Do trying-on and posing and picture-taking - the bodily encounter with the kimono, in short constitute a different kind of doing than the embodied act of looking? The protesters in Gallery 208 certainly seemed to think so and so did counterprotesters who hailed the event as a way to appreciate and share Japanese culture (not necessarily European art history) with the public.

Although cross-cultural representation and 'cultural exchange' are hot issues in contemporary discourse, both popular and academic US discussions seem to repeatedly stall in a binary, simply and alliteratively summed up as 'appropriation' and 'appreciation'. Headlines regarding movie casting, Halloween costumes, fashion shows and (in May 2018 as I edited this article) a white Utah high-school student's qipao-/cheongsam-style vintage prom dress each kick up their own wake of defences and condemnations, but conclusions rarely seem to emerge when the dust settles. Most of the general coverage of the kimono protests controversy fell into just such a familiar plot. The museum presented its Kimono Wednesdays programme as a fun, 'flirty' appreciation of a famous piece of art and (presumably) Japanese culture; counterprotesters and many news outlets in Japan agreed. Decolonize Our Museums, however, paraphrases the MFA stance and replies to it in its FAQ catechism:

\section{e. This is appreciation, not appropriation.}

The way this programming was framed and curated makes it appropriation, not appreciation. ${ }^{10}$

As if there were only two mutually exclusive sides to this kimono.

In this article, I use the kimono as a jumping-off point to think through some issues of contemporary cross-cultural performance, trying to articulate the current stakes of 'cultural appropriation' - in part through a brief history of kimono and its international, transcultural influences over time - and to think through the ramifications of current conceptions of appropriation, cultural capital and their differing valences within and beyond the United States. At stake in my attempt to parse the currents and cross-currents of debate in the kimono protests are the loaded terms 'orientalism', 'exotification' and 'racism', all filtered through my own point of view, which favours approaches sensitive to discourses of 'performance', 'performativity' and 'theatricality'. The kimono protests, while never all that big, and never all that controversial, nevertheless constitute an important scene wherein we can examine the collision of multiple forms of politically charged performance: cultural appropriation, racial identity, transnational 'exchange' and anti-theatricality. Further, I argue that it is precisely on the ground of the 'not-that-serious' that performance scholars need to intervene: our 'objects' of study (performance, theatre, representation) tend to teeter ambivalently between attributions of deep significance (political, psychological, social) and apparent triviality (mere entertainment, imaginary, dress-up, commercialism). It is perhaps precisely at the level of the seemingly frivolous that we can begin to hammer out more nuanced overtures to intercultural reconciliation and understanding. 
In a July 2015 post about the kimono protests on Oxford University's Practical Ethics blog, UK-based ethicist Kei Hiruta observed that

the wrongness of Orientalism is considered so self-evident that those commenting on 'Kimono Wednesdays' have largely focused on whether the event is Orientalist, sidestepping harder questions as to specifically what is wrong if the event is Orientalist and (assuming, for the moment, that it is indeed Orientalist) whether the wrongness of Orientalism should override other considerations. ${ }^{11}$

Hiruta's caveat obliquely references the ways in which contemporary culture treats certain concepts as settled: orientalism, as a species of racism (just like appropriation) is 'bad' - we have, of course, known that ever since 1978 when the eponymous book by Edward Said came out. By starting back before the settledness of orientalism's 'self-evident' badness, Hiruta's invitation entails re-evaluating any simplistic assumptions we may be making about the immanence of culture's meanings and messages, especially as it traverses national boundaries, generations, institutions and individual bodies. Similarly, in a 2014 article in The Atlantic, fashion scholar Minh-Ha T. Pham demonstrates how orthodox discussions of appropriation can obscure the agency, creativity and acquisitive actions of the originators of the cultural objects then 'appropriated' by Western (white) cultural arbitrators. Using a contemporary example of the plaid plastic carrier bag, globally synonymous with internal and external refugees, immigrants and poor people, remade as high fashion satchels, Pham notes that the appropriation/appreciation binary predetermines the terms of every debate by foreclosing the specifics. The anti-appropriation camp reify a binary divide between passive victims and Western thieves and thus 'preserve the hierarchical relations between the fashion industry and the cultures being appropriated'. ${ }^{12}$

Pham proposes one way to get past the stultifying binary of appropriation/ appreciation in fashion criticism is to "engage in an "inappropriate" discourse, one that reframes the debate to include all the things that are not carried over when white Western creators swipe from elsewhere'. In my reading of Pham, an inappropriate discourse need not foreclose noting an ethical wrongness in the 'appropriative' action in question, but rather, in refusing to reduce individual cases to the construct of the thief-victim dyad, restores the context, detail, history and complex considerations which tend to be foreclosed in binary right/wrong discussions and which, I contend, are most important in forging long-term solutions to the problems of cultural exchange and hybridization.

To add to Pham's proposal, I suggest we also consider inappropriation - actions, behaviours, and performances as themselves contributing to 'inappropriate discourse'. The kimono protests in Boston in 2015 furnish a particularly rich and complicated example of inappropriation. The common sense of 'orientalism is bad' collided spectacularly with the common sense of 'sharing culture is good', amply demonstrating the importance of Hiruta's and Pham's reminders that seemingly obvious ethical dicta can obscure more than they illuminate. Where Hiruta uses the keyword 'orientalism' to anchor his discussion, and Pham uses 'appropriation', I will be attempting to work back and forth between both those terms. In defence of what 
may seem like an irresponsible elision, I want to recall the DOM protest sign that pithily summed up the imbrication of these terms as if they were interchangeable: 'THIS IS RACIST. THIS IS APPROPRIATION. THIS IS ORIENTALISM'. Our inappropriate task, then, will be to articulate these tangled and elided terms and claims by restoring the detail and information stripped away by protesters and museum alike. In this article, I want to take up Hiruta's and Pham's invitations by starting with the thing itself: the kimono.

\section{Some 'thing to wear'}

What is Japanese about the kimono? Perhaps its very simplicity - rectangular sleeves and overlapping front panels - helps the kimono to function as an unmistakable symbol of Japaneseness. Surely the transliterated name from Japanese into English pronunciation ('kuh-MO-no' or even 'kimona') maintains some of that exoticism as well, even when the specific details of the garment so denoted depart wildly from standard Japanese constructions. I think we can safely say that kimono - the word and the garment always connotes some degree of Japaneseness, be it the physical country or the fantasy orientalist 'Japan of Pure Invention' (as Oscar Wilde put it). We might, then, consider the kimono a 'scriptive thing', a term coined by Robin Bernstein to describe a thing which, 'like a play script, broadly structures a performance while simultaneously allowing for resistance and unleashing original, live variations that may not be individually predictable'. ${ }^{13}$ The MFA's two kimono, for example, clearly denoted some sort of Japanese essence so that both proponents and opponents identified every embodied encounter with it as some sort of performance of Japaneseness (either as 'cultural exchange' or mockery or orientalist fantasy). Camille Monet's experience with Monet's kimono was Japanese enough to warrant the naming of the painting of her and it 'La Japonaise' - as if donning it performatively turned the French woman Japanese. This, it is worth noting in passing, was not an isolated slippage - many European paintings of women in kimono refer to Japanese women, when they clearly present renderings of models with phenotypically European features wearing imported Asian clothing. ${ }^{14}$ When it comes to artistic representation, it is hard to articulate where to locate the transgression between European and Asian: in a joke about 'dressing up' and pretending, or in the artist's intention despite lacking skill in portrayal or access to an actual Asian model, or some other inchoate place between material thing, human body and artistic object. Whether one imagines the transformative power of the kimono as firmly limited to the theatrical realm of costume and fantasy or not, the kimono remains an overdetermined object, symbolic and physical medium of the pleasures and pitfalls of cross-cultural exchange in our contemporary post-colonial, globalized paradigm.

'Kimono', though, for all its ancient, archetypical connotations, is a fairly recent invention. The word 'kimono' means literally 'a thing to wear' (着物) and it came into common parlance in Japan during the same period that it entered foreign languages such as English: in the second half of the nineteenth century, after two and a half centuries of stringently policed political isolation in Japan was forcibly ended 
by Matthew Perry and the United States Navy in $1853 .{ }^{15}$ Prior to the new influx of foreigners and the post-1868 official Japanese embrace of foreign influence over all aspects of Japanese society, there had been no need for a catch-all word to describe Japanese typical dress. The emperor changed his clothes from traditional imperial court dress to a Western-style military uniform in 1872, in conjunction with an official proclamation instructing others to do the same, and the empress permanently changed to European dress in 1886. Only in this new milieu of foreign import and international exchange would Japanese native dress be binarily understood as forming a unity distinct from foreign-import clothing styles. The words wafuku (和服) and $y \bar{o} f u k u$ (洋服) for 'Japanese dress' and 'foreign dress' were invented. ${ }^{16}$ As more and more members of the population adopted more and more articles of Western dress (military uniforms were some of the earliest, then civil service uniforms, men's clothes, school uniforms and, much more slowly, women's everyday dress and uniforms), wafuku rapidly took on new and different meanings. The wide variety of wafuku forms that had reflected class and caste distinctions, uniforms for labour and specialized clothing for certain activities, began to be subsumed into a more generalized, singular kimono style (most iconic of the samurai) that was representative not of all those granular distinctions amongst different people, but rather of a generalized Japaneseness. ${ }^{17}$ This national sense of identity had not existed with much distinction until there was a present and insistent not-Japanese to catalyse it, and an influx of new things, practices and people to be designated as yo (洋 foreign, ocean) to the Japanese $w a$ (和 Japanese, harmony).

In other work, I have examined more extensively the circumstances by which the change to $y \bar{o} f u k u$ occurred, but for our purposes, it suffices to note that, by the late twentieth century, kimono had become a highly rarified, ceremonial dress. ${ }^{18}$ Even (or especially) as the kimono has fallen out of everyday use and become a highly specialized, mostly formal or archaic garment, its mystique as a quintessential emblem of Japaneseness seems to have grown. Stringent hierarchies of formality and appropriateness and entire schools dedicated to learning how to dress oneself have sprung up, 'preserving' the traditional kimono in the mummifying manner of salvage anthropology - helping to kill its object under the guise of documenting it. ${ }^{19}$ Kimono in Japan is now largely worn only on specific holidays and ceremonial occasions like weddings, funerals and coming-of-age day or by people with specific jobs: geisha and other traditional entertainers, tea ceremony practitioners and some traditional innkeepers. Today, the vast majority of Japanese people hire dressers or go to rental studios if they need or want to wear kimono, both because it takes expertise to wrap and tie the kimono and also because the standards of 'proper' wear have become more and more stringent as it has retreated from everyday use. ${ }^{20}$

Despite their modern status as the quintessence of Japaneseness, kimono are fundamentally international, beyond the fact that the word coalesced around the germ of foreign influence. Like innumerable other aspects of Japanese culture, the prototype for the range of garments now collectively called kimono came from Chinese influences, although they have grown over the centuries into unique styles. ${ }^{21}$ In the sixteenth century, the first direct contact between Japan and European mariners, 
primarily Dutch merchants and Portuguese missionaries, brought new influences in design motifs and colours to Japanese fashion as well as some fashionable new accessories, like rosaries, as documented in early depictions of Izumo no Okuni, the woman to whom the invention of kabuki is attributed. ${ }^{22}$

When Japan re-embraced the rest of the world in the mid-nineteenth century, it took time to change clothes permanently to $y \bar{o} f u k u$, since tailoring Western-style clothes was a specialized skill that took time to learn and favoured $y \bar{o} f u k u$ fabrics (especially wool) were rare in Japan. Nineteenth-century Western women's dress was particularly expensive and complicated to make and wear - exactly the problem most people have now with kimono. ${ }^{23}$ Further, a gendered bifurcation between 'public' and 'private' duties (in that men were tasked with presenting a modern face to the rest of the world and women were deemed responsible for the private, domestic work of ryosai kenbo ('good wives and wise mothers')) also affected the kimono's fortunes: wafuku was associated with private life, while yoffuku played an important role in Japan's bid for international political equality through appearances. Meanwhile, other aspects of clothing changed more rapidly: aniline (synthetic) dyes (invented in Britain in the 1850 s as a by-product of attempts to synthesize quinine) rapidly made their way into Japanese production of fabric as well as ink for woodblock prints and the wide surfaces of the kimono and juban (under-kimono) proved a ready canvas for additional engagement with the outside world. Just as visual artists rapidly invented a popular new genre of woodblock print: the Yokohama-e and kaika-e (pictures of foreigners doing foreign things and pictures of new 'enlightenment' things like locomotives, clothes, architecture and so on), textile designers and manufacturers adopted the same visual influences into fashionable new kimono that incorporated images of new items and influences rather than directly reproducing them.

Perhaps my favourite example of these self-consciously international kimono was created in honour of President U. S. Grant's 1879 visit to Japan. This visit, the first time an American (former) president visited the country, was hugely celebrated in Japan with processions, events and a full social schedule. At a special performance for President and Mrs Grant, a group of Tokyo geisha danced in specially designed stars and stripes costumes (see Fig. 2). ${ }^{24}$ Clara Whitney, an American missionary's daughter who was in attendance, described in her diary

a street scene in Tokyo, all illuminated by lanterns with flags ... a line of girls, dancing as they came, advanced simultaneously from the door of either vestibule, waving their fair hands and keeping time with sandaled feet. What made the blood rush with a thrill through the hearts of the Americans? What in the appearance of these girls made thousands of sweet memories and patriotic thoughts arise in our minds? Ah, the old flag, the glorious Stars and Stripes! ... Each girl was dressed in a robe made of the dear old Stars and Stripes, while upon their heads shone a circlet of silver stars. It made the prettiest costume imaginable. The stripes constituted the over-robe itself while one sleeve slipped off from one shoulder revealed a sleeve of stars below, their girdles were dark blue, sandals, red and white, and presently they took out fans having on one side the American and upon the other the national flag. ${ }^{25}$ 


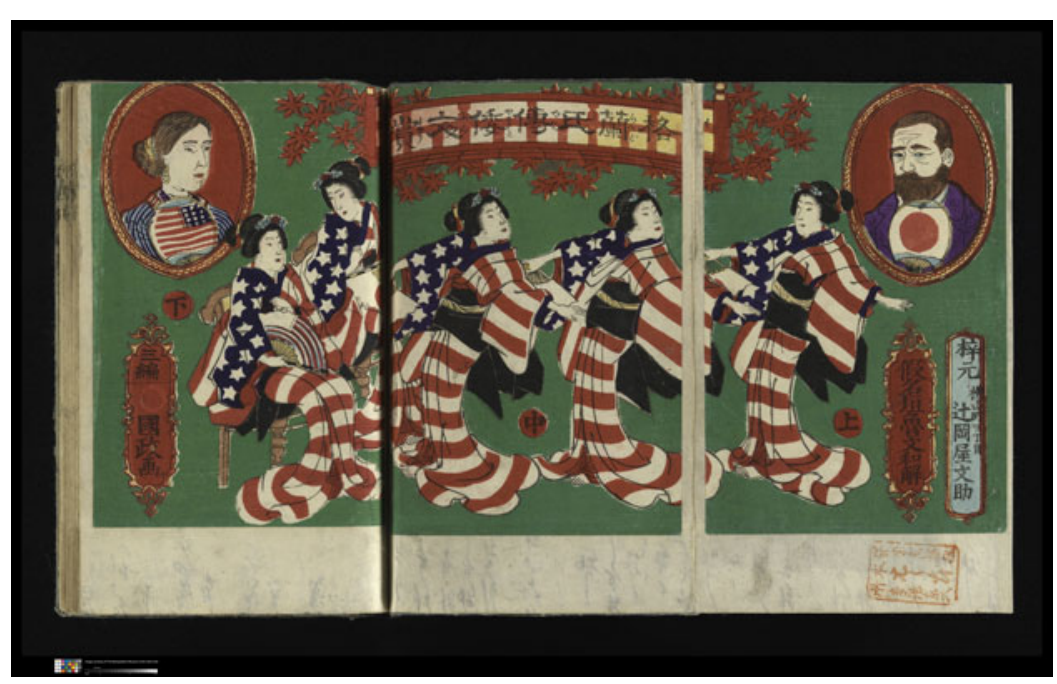

FIG. 2 (Colour online) Stars-and-stripes geisha from The Life of President Grant in Japanese (Gurando-shi den wabunshō, 1879) by Utagawa (Baidō) Kokunimasa. Image courtesy of the Metropolitan Museum of Art, Mary Griggs Burke Collection, Gift of the Mary and Jackson Burke Foundation, 2015.

We could look at the stars-and-stripes kimono and other modern and international motifs as a contrasting strategy to adopting $y \bar{o} f u k u$, one which cannily preserved a sense of selfhood while gesturing to the new dominant paradigm of 'modernization' and Westernization. Of course, shifting motifs was faster and easier than changing the entire infrastructure of apparel manufacture (a process that was not completed until roughly the 1950s), but this specific kimono adaptation can also be seen as a strategy of 'domestication' of foreign influences. Most importantly, in surveying the period since the 1850 s, we should note that Japanese sartorial strategies, like the stars-and-stripes kimono no less than the origin of the kimono, do not break down into a neat binary between 'indigenous' kimono and foreign dress, but rather are always constituted in imbrication with each other within and beyond the boundaries of the Japanese archipelago.

In fact, during the early twentieth century, imperial Japan weaponized the recently cemented Japanese essence of kimono in their Asian colonies. In a precise inversion of the Meiji makeover bid to gain Western-style imperial power by means of 'dressing the part', by the 1930s, occupiers, particularly in Taiwan and Korea, were encouraging local women to adopt kimono as a means to inculcate a sense of Asian racial unity that simultaneously demonstrated Japanese cultural supremacy. In her work on the use of kimono in colonial contexts, Rie Mori posits that it was precisely the essentialist associations that Japonist Europeans had established between Japanese women and kimono that were in turn seized upon by Japanese occupiers in Asian colonies to further their goals of 'greater East Asian co-prosperity' under Japanese leadership. ${ }^{26}$

Japan's sartorial practice on both sides of the imperial power dynamic is particularly instructive as we turn back to the kimono of the MFA kimono protests: in a distinct departure from the typical Said construction of orientalism's active 
Western appropriator and passive, feminine oriental appropriated object, we could also conceive of kimono propagation as a Japanese strategy of 'soft power' which may indeed be traced all the way back to Japan's active participation in the late nineteenth century's world fairs and expos - including the one that facilitated Claude Monet's purchase of a red kimono in 1876. Japan's active support of export activities does not, however, bear on whether Europeans and North Americans were simultaneously revelling in orientalist and exoticizing attitudes under the banner of 'Japonisme'. As a simple Google search for 'Japonisme' or a turn through the late nineteenth-century wing of a European art museum shows, kimono proved to be a particularly popular and evocative export item and remains a fraught symbol of the promise and perils of intercultural exchange.

Key to the kimono's status as a particularly overdetermined orientalist thing is the fact that you put it on. The kimono, as an item of clothing, comes to have meaning via the intertwined valences of body, garment and actions taken, none of which are effaced in the combination - which is to say, the meaning of kimono is constituted through performance. For example, the perceived appearance (such as gender and race) of the body wearing the kimono (and how the kimono itself looks and seems) and what those clothed bodies do matter hugely to how the body and the kimono come to mean. It is a patent tenet of orientalism that such collective rules of the interpretation of bodies and culture cut both ways. Where a white body in a kimono may read as fashionable, louche and bohemian (or alternatively - and increasingly - crassly colonial and oppressive), the Asian body in the kimono may be just as limited to a sense of naturalized exoticism, romantic atavism and fetishization. ${ }^{27}$

Both attitudes - disproportionately gendered feminine - are on display in $L a$ Japonaise. Mary Mathews Gedo catalogues a range of responses to the painting in 1876: while many enjoyed it, several critics declared Camille's attitude, and especially the placement of the character (holding an unsheathed sword) depicted on the kimono, to be obscene. One critic described La Japonaise as showing 'a Chinese [sic] in a red robe who has two heads; one of a demi-mondaine on the shoulders, another of a monster, placed - we do not dare to say where'. ${ }^{28}$ However, La Japonaise seems scarcely erotic considering how little female flesh is on display in contrast to other Japonist paintings, which exploited the conflation of Japanese exotic dress with exoticized flesh, such as Tissot's 1864 Japanese Girl Bathing and/or the imported kimono's association with déshabille amongst European women. ${ }^{29}$ The critics' propensity to label even a portrait of Monet's very covered-up wife a 'Chinese demi-mondaine' due to her being enveloped in a red kimono accents the strength of the kimono's scriptive power to attribute exoticized sexuality to its wearer.

Further, Camille's kimono (as well as many of the other kimono depicted in nineteenth-century Japonist paintings) was not an 'ordinary' kimono, but uchikake. Today uchikake are generally only worn by brides at weddings and kabuki actors onstage. The motifs on Camille's kimono indicate it was a kabuki costume, something that long-time Japonophile Monet himself knew, including the fact that all kabuki actors were men. ${ }^{30}$ This means that MFA visitors were 'learning Japanese culture' by pretending to be a French woman pretending to be a Japanese woman by wearing a replica of a theatrical costume meant to be worn by an onnagata - a male player of 
women's roles - who had himself been pretending to be a Japanese woman, likely a courtesan character. That is, there are no Japanese women physically present at all, in a controversy centered on a painting named La Japonaise.

Does it matter that both the kimono in the painting and its replicas were theatre costumes all along? That museum visitors had been invited to 'channel their inner Camille Monet' not 'inner Japanese woman'? That the painting itself may be a parody? What are we to make of the performative power and history that the kimono seems to have been ascribed by both the protesters in 2015 and the Euro-American Japonist painters who ascribed Japanese identity to so many of the subjects in their paintings? What, then, does putting on a kimono do? In the remainder of this article, I will revisit the point-counterpoint of the swirl of argument that surrounded the kimono in Gallery 208 in 2015 to forge a path beyond the binary of appreciationappropriation. In general, we will see that protesters tended to adopt a fundamentally antitheatrical ethical stance while opponents (especially Japanese interlocutors who had varying amounts of exposure to the details of what was happening on the ground in Boston) tended to identify a different sort of cultural power in the performative proliferation of the kimono, one for which we have already seen historical precedence. In threading our way through these opposing camps, I will endeavour to lay out a ground plan for addressing these thorny issues of representation through the definition of what I call a theatrical ethic of inappropriation.

\section{Protesters}

Just as Monet had named his painting of his French wife La Japonaise, many critics of Kimono Wednesdays, both online and in person, identified the act of putting on a kimono as an act of performatively turning Japanese - either in mockery, as a costume or dress-up, or (perhaps?) seriously. For example, a comment beneath the original MFA publicity photograph for Kimono Wednesdays on Facebook (featuring a young, apparently white woman, copying the pose in La Japonaise behind her) declared, 'This is honestly one of the most vilely racist things I've ever seen. White folks wanting to play dress up and feel Japanese? Please, don't'. ${ }^{31}$ Although we have already established that indeed the MFA's invitation was much closer to inviting 'folks' to dress up as a French woman dressing up to only maybe feel Japanese, this comment exemplifies the typical disapproving reaction.

More complicated was the attitude encapsulated by a sign from the second protest: 'The MFA is all about cultural experiences. Try on the kimono [in stereotypical 'oriental' font] Learn what it's like to be a racist imperialist !!! TODAY !!!' First of all, I want to assert that one does not have to try on a kimono to learn what it is like to be a racist imperialist; the sign suggests that there is a key difference between trying on the kimono and looking at the painting it is copied from. No one, remember, was protesting the painting hanging in Gallery 208 until there was the option to try on a kimono in front of it. The sign implicitly suggests, then, that you learn racist imperialism when you do it in performance, rather than by looking at it, or living and breathing in a society founded and foundered on racist imperialism. Indeed, most 
defenders of the programme did not feel a sense of racist imperialism at all when they tried on the kimono, which, if you can learn anything by not feeling it, is probably exactly how most racist imperialists feel about their racism and imperialism.

Or possibly there is a difference between 'putting on', which is what I wrote, and 'trying on', which is what the sign actually claimed would teach you what it is like to be a racist imperialist. How many ways are there to put on a kimono? And what factors determine the status of an action? Here the protesters seemed to be repeating as tragedy what the Monet painting had enacted as parody, revealing a slippage between performativity and theatricality: does trying on the kimono performatively make you a racist imperialist? Or only make you like one? And strangely, here it is the playful theatricality of 'dress-up' in kimono that performatively turns the museum guest into a racist imperialist, not (presumably) whatever a serious putting on of clothes entails. While, of course, presuming that one was not always already a racist imperialist before doing the donning. For example, consonant with the Facebook commenter who found Kimono Wednesdays 'one of the most vilely racist things [she'd] ever seen', one of the hashtags chosen by the DOM protesters was \#whitesupremacykills. 'White supremacy kills' is not a controversial claim in critical race studies. However, here is how it played out on Twitter: up until 24 June 2015, \#whitesupremacykills was being used in conjunction with the Charleston shooting (one week earlier, 17 June 2015), in which, yes, a twenty-year-old white supremacist named Dylann Roof carried out a mass shooting, murdering nine black people inside a church in South Carolina. Suddenly, the feed changed to pictures of people in a fancy art museum with a gorgeous red silk kimono.

The juxtaposition jars, but clearly, by this point for protesters, the kimono in the gallery had taken on sins far greater than Claude Monet's ambivalent relationship with Japonisme: 'I have been assaulted, raped, harassed, and stalked, denied my humanity, and you don't want to think about me because I'm just another JAPanese woman', declared one sign. ${ }^{32}$ Indeed, an injured minority subjectivity began to adhere to the kimono itself when DOM co-founder, Pampi, tweeted, '@MFABoston didn't rly cancel. Kimono still on display to be felt it [sic] up under creepy Orientalist gaze $n$ touch'. In another tweet, Pampi makes her perceived elision clearer: 'touching kimono w/o adequate curation condones nonconsensual touch and worse on feminine asian and othered $\mathrm{ppl}^{33}$

Plenty of critics argued that claims like these reveal an inability to distinguish between 'serious' and 'trivial' concerns, that DOM comprise a variety of those college 'snowflakes' unable to deal with the quotidian vagaries of modern life. ${ }^{34}$ However, we could also articulate this situation as an antitheatricalist problem. As is frequently worth recalling, antitheatricalists do not underestimate the power of theatre, but rather they tend to ascribe great performative import to 'theatrical' acts; Plato's declaration in The Republic that one must not imitate the inferior things for fear of becoming like them probably remains the premier example of this attitude. For the kimono protesters, trying on the kimono could not be simply for fun - over and over the disapproving identified putting on kimono as an attempt at somehow 'turning Japanese' - with the effect, apparently, of actually becoming, or becoming like, a 
'racist orientalist'. The mercurial oscillation of performance's mattering or not mattering (we might name this 'theatricality'), the possibility that people try on kimono with different intentions and come away with different experiences, even the possibility that non-white, non-American museum patrons might want to try the kimono were all discounted in DOM's antitheatricalist stance.

DOM clashed with the majority in their insistence on the deep importance of this form of play against the majority opinion of light fun and pleasantly entertaining cultural appreciation (or indeed, even if one thought the activity inappropriate, those who discounted it as unimportant or trivially incorrect would also be beyond the orbit of DOM concerns). The link between orientalizing and exoticized images of Asian and Asianized women (like La Japonaise) and the persistent fetishization of Asian women in the US is undeniable, and yet it remains a struggle to decide how exactly to evaluate the inchoate effects of imagery as material damages to individual psyches or as effecting prejudices against certain groups. DOM's tactics attested to the enmeshed nature of desire and oppression, violence and entertainment, but sometimes at the expense of equating, or even replacing, racially motivated mass murder with museum dress-up kimono. The theatre costume shop replica of a nineteenth-century theatre costume had itself, it seems, been hyper-exoticized by the protesters who imbued it not only with an ontological Japaneseness which it seemingly unfailingly transferred to wearers, but also with a sense of its own vulnerable (indeed traumatized) subjectivity.

\section{Counterprotesters}

Meanwhile, the counterprotester Timothy Nagaoka asked,

Isn't it stereotyping on the protesters' part to say that kimono represents Japan and to put so much weight into just wearing a kimono? For a Japanese person, kimono is just clothing, and there's really nothing sacred to it. And I feel it's the protesters who placed the kimono up on a pedestal. ${ }^{35}$

Amber Ying, a founder and primary spokesperson for DOM, described the crux of their protest as 'who speaks for whom' amongst institutions and communities - but this is also precisely the point upon which many counterprotesters and opponents centred their responses. Both sides' shared agreement on the essential 'Japaneseness' of the kimono and the distillation of the try-on activity down to some form of 'turning Japanese' helped to ensure that the ethnic origins of protesters seemed salient to many observing the protests unfold. Ying and her co-founder Pampi are Chinese American and Indian American, respectively, and very few protesters claimed to be Japanese or Japanese American. ${ }^{36}$ While it seems that there was at least one protester of Japanese descent present at at least one protest, Japanese expatriates and Japanese Americans primarily appeared on the side of the counterprotests. Several Japanese news outlets picked up the story, with the most outlandish even suggesting that foreign provocateurs (meaning Chinese spies) were attempting to derail Kimono Wednesdays out of anti-Japanese prejudice. ${ }^{37}$ 
Japanese and Japanese American counterprotesters' claims about sharing culture and the positive appreciation of Japaneseness did not necessarily discount the power of representation. Rather, they located a different power of Japanese desirability in the proliferation of images of Japaneseness. Indeed, even far more questionable imitations of Japan are generally approved by Japanese observers, as a brief survey of recent kimono-appropriation controversies confirms. One Japanese YouTube vlogger documents young people on the street in Tokyo being shown Katy Perry's eye-shattering neon-orientalist qipao-kimono mashup outfit, scenography and back-up dancers at the 2013 American Music Awards show. ${ }^{38}$ They are nonplussed by explanations that the performance evoked outrage and universally agree that they appreciate foreign interest in Japanese culture. In just the time since the kimono protests, numerous additional examples of so-called 'yellowface' and 'whitewashing' have cropped up in international media, demonstrating the same divide between Asian American critiques and Japanese approbation. A short list would include a March 2017 US Vogue magazine photo spread starring white American model Karlie Kloss in a black geisha-reminiscent wig and kimono-like fashions shot on location in Japan, a Utah child's 'geisha'-themed birthday party from 2012 that made the rounds again in August 2017, and the 2017 remake of Ghost in the Shell, an anime and manga story whose protagonist, Motoko Kusanagi, was played by Scarlett Johansson in the Hollywood film. 'I am Japanese, in Japan at this very moment. The only people who think culture shouldn't be shared are racists like you', reads one comment in the back-and-forth argument on the Tumblr entry about the child's geisha birthday party. Over and over again on Internet discussions of appropriation, a version of this comment (with two constituent parts: (1) I am [salient ethnicity], (2) It is racist NOT to perform cross-culturally) is presented as the 'end' of the argument. ${ }^{39}$ While the foregoing comment demonstrates how Japanese identity functions as a trump card to end debate, the attitude functions oddly by opening up performance as freely available but foreclosing discussion at the level of authority: the Japanese have declared, everybody can wear kimono, however they want.

Japanese approval of kimono's global dissemination is not necessarily altruistic: as we have seen, Japan already has over a century of experience exporting kimono for political and economic purposes. Since the eclipse of kimono as daily wear by the mid-twentieth century, an entire hierarchy of kimono business and culture enterprises predicated on 'saving' the 'dying tradition' of kimono wearing and manufacture have sprung up in Japan, from kimono rental and 'transformation' into geisha and maiko dress-up packages to high-end kimono designer Hiromi Asai’s 2016 New York Fashion Week kimono fashion show, featuring the standard parade of dour multicultural models, but all in kimono. Japan Times articles on the kimono protests consistently linked Boston with concerns that protests would adversely affect attempts to stabilize Japan's kimono industry. In a larger sense, however, financial profitability and the perception of cultural desirability (no matter how egregiously inaccurate) regularly and historically have trumped most concerns about the 'authenticity' or exclusivity of culturally marked products. While it is surely impossible to pinpoint a single reason why such a contrasting attitude prevails in Japan, just one contributing 
factor is likely the belief that Japaneseness is a unique and indelible essence, a prevalent social attitude and hotly contested field of study both identified with the term Nihonjinron, typically translated as the 'theory of Japanese uniqueness'. In a certain sense, then, the more outlandish the representation of Japaneseness, the less likely it is to upset a sense of inborn Japanese essence, while connoting a sense of 'cool Japan' cultural desirability. Thus, in contradistinction to the DOM recourse to antitheatricalism, the counterprotest and allied narratives located a power in theatrical proliferation, simultaneously articulable as a nationalist sense of Japanese soft power and a broader gesture toward a global culture of multicultural appreciation.

\section{A theatrical ethic of inappropriation}

Most of the furor wound down with the end of the Kimono Wednesday programme at the end of July 2015, although at least two panels were held to discuss the controversy and its larger ramifications, one hosted by art blog Hyperallergic in New York and one at the MFA in January 2016. Then, in April 2016, the Netflix sitcom Unbreakable Kimmy Schmidt belatedly doubled down on the kimono protests and the show's own previous racial controversy in the third episode of season two, entitled 'Kimmy Goes to a Play'. ${ }^{40}$ The episode imported the performative concerns of the kimono protests directly into the theatre: in the episode, struggling actor-cum-Times-Squarecostumed-performer Titus Andromedon mounts a one-man show entitled Kimono You Didn't in which he recounts one of his former lives as a Japanese geisha named Murasaki.

Titus is shocked and confused when, before they've seen the show, Asian American activists (and one 'transracial' activist) name him one of the top five Hitlers of all time in fury that a black man would presume to perform a Japanese woman character. Real Hitler, he reports despairingly, isn't even on the list. After an angry confrontation, the protesters are induced to take seats in the theatre, where Titus wins them over with the sincerity and beauty of his performance and the protesters are left bereft of their offence. The viewer sees a two-minute montage of Titus's show, featuring Tituss Burgess in white makeup and a purple kimono singing in a plaintive soprano falsetto interspersed with bits of monologue about Murasaki's difficult life. Kimmy Schmidt itself does not definitively decide whether Titus's reincarnation is true or false (though viewers are treated to a montage of Titus's previous incarnations as various genders, ethnicities and species), but the emotional effect of Titus's race and gender cross-dressed performance is to win over his initially hostile audience, primarily through the emotion conveyed through his beautiful singing in Japanese. The leader of the protesters hugs Titus after the show and tells him he hasn't heard Murasaki's song since he was a little boy.

Some critics viewed the episode as a doubling down by the show's creators on earlier crassness about race and certainly the episode could be interpreted as more severely mocking the protesters' ire, especially their Internet-enabled tendency to condemn in advance, than Titus for the delusion of playing Japanese. What I want to focus on is the potentiality that Titus's show presents, one that is suggested by the performance's happy 
outcome: the patent wrongness of the (re)appearance of Murasaki in Titus's black, queer, southern, sizable male body is presented as having nevertheless got something right about cross-cultural understanding. ${ }^{41}$ Focusing on whose body is 'correct' in kimono obscures the fundamentally international origins and development of the kimono, the naturalized assumptions made of Asian bodies in kimono, and the complicated non-visual routes by which 'culture' and 'identity' travel. Just as orientalist representations of Japaneseness, like Camille Monet's red uchikake, have bled across the boundaries of nationality to impact the Asian American experiences of the protesters (and counterprotesters, and bystanders), so the kimono in the museum cannot be comfortably assigned to a single authoritative 'owner': neither the MFA's predominantly white docents, nor Boston-area protesters, nor the Japanese and Japanese Americans' claims to authority can preclude the legitimacy of the other parties' concerns.

In the end, I do not believe it is important to decide in retrospect whether the MFA should or should not have produced and promoted Kimono Wednesdays; the event is much more valuable for demonstrating the impossibility of making that choice and the impossibility of attributing ownership to culture and its symbols. Focusing on attributing ownership of cultural property advantages Japanese interlocutors while insufficiently acknowledging the very real ways in which orientalist image making has affected the Asian American experience of the non-Japanese protesters. However, acquiescing to DOM demands to control the narrative of the Kimono Wednesdays programme had the effect of stifling the will of the majority and subsuming the multiplicity of Asian transcultural experiences under a hyper-specific American rubric.

One of the most scrupulous reporters on Kimono Wednesdays, the 'Japanese American in Boston' blogger Keiko Kawabe, pithily pointed out a major flaw to DOM's 'Stop Appropriation' campaign: 'Many people, including Japanese Americans and Japanese felt that the mainly non-Japanese American protesters had appropriated a Japanese cultural event for their own agenda'. ${ }^{42}$ The obliterating effects of binary arguments about appropriation could be seen even more starkly in the way in which concerns over the 'vilely racist' kimono dress-up overwhelmed the vilely racist Charleston shooting with the hashtag \#whitesupremacykills. Instead of demonstrating the complicated imbrication of orientalist fantasy and racially motivated mass murder, one appears equivalent to, or even subsumes, the other.

Where arguments around appropriation have tended to make claims about ownership (as in the construction 'taking from a culture that is not your own'), and accuracy or 'authenticity', the contextual power dynamics of the groups involved have been conflated with a theatrical question of accuracy in representation or performance. That is, what dynamics appear when we restore the context to cross-cultural performance, asking what group defines the meaning of the performance? How many groups can lay claim to a stake in the representation and how can we craft performances that contain as much of that information as possible? And, importantly, when can we use our opportunities for thought and debate not to insist on simplifying and binarizing the situation, but on complicating and expanding it?

In proposing a theatrical ethic of inappropriation, I am arguing that 'accurate representations' are not synonymous with 'justice' - that demanding a 'correct' 
representation is no proxy for fair treatment or redress for oppression. For example, although Titus Andromedon's portrayal of a geisha is clearly all wrong visually, even skirting dangerously close to parody, we are offered the possibility that an honest attempt at empathetic surrogation may succeed at transferring something meaningful across bodies and subjectivities (character-performer-audience). In real-life cross-cultural performances like Kimono Wednesdays, the moral of the story is often more ambiguous than Titus Andromedon's television scripted triumph; indeed, the very theatricality of the twenty-first-century costume-shop copy of the nineteenth-century kabuki costume further confused the clarity of what a sartorial performance could be said to have done or communicated at Kimono Wednesdays. Trying on the replica kimono and posing like Camille Monet might constitute a recurrence of the troubling dynamics of nineteenth-century orientalist exoticizing; it might remind us that the legacy of these habits of imagination and desire are still with us. But, as scholars of Richard Schechner, Judith Butler, Joseph Roach and many others, we remember that every repetition also constitutes a difference - that the key to breaking a cycle may also lie in 'the possibility of a different sort of repeating., ${ }^{43}$

The possibility that we might understand something, even partial, flawed, or silly, across the boundaries of race, gender, sexuality, nation and so on, is a possibility that we cannot afford to give up. Neither, though, does this mean that representations should try to hold themselves immune from critique. The moral and ethical valences of representations are, of course, contingent on the context of their deployment. Being precise about the relationship between Kimono Wednesdays, white supremacy and colonial legacies may, then, paradoxically, require acknowledging that the kimono represents exoticized orientalism and the contemporary soft-power cultural exchange of 'cool Japan' and some legitimate and necessary, if messy, cross-cultural curiosity and desire. Importantly, such valences are probably not even articulable. The kimono thus functions multifariously, activating people's senses of difference and familiarity, desire, curiosity, history and aesthetics. Our recognition that desire and representation have been deployed oppressively cannot foreclose our attempts to represent, to understand better, to facilitate negotiation of the teeming multiplicities of feelings, desires and denials that come with the impossible situation of decolonizing cultural exchange, of fostering reparative discourse and intercultural interaction. To, if you will forgive a Beckett paraphrase, offered sincerely, fail better in our attempts to understand each other.

Theatre takes as its fundamental axiom that one may substitute for another. That a chair may be a mountain, that an empty space may be a horse. (A French woman might play Japanese; the present-day museum-goer might re-enact a Japonist painting.) One thing may be interchangeable (for the time being, for the defined moment) with another, and despite a performance's brevity, we know that these effects can be long-lasting. (Whiteface make-up and chopsticks in a bun still signify some Hollywoodized notion of 'geisha'.) Performance is sticky even as it is momentary and fleeting. The apparent transitoriness of performance may embolden some performers and observers to view their performances in a vacuum, as if they are not haunted by all the other performances where the magic of standing in was used in oppressive ways, as a mode of violent control of bodies or of curtailing certain people's horizons of 
possibility. As theatre specialists, we should be particularly attuned to parsing out the ethical ramifications that follow from taking seriously the arts of substitution. To address the long sticky history of how representation - impersonation, surrogation, performance - has been used to oppress, to insist on recognition of that fact from those who feel no such weight when they don (for example) a kimono, constitutes a right and an injunction to ethical representation that is the responsibility of everyone, not just a few college-age protesters. We need to be articulate about decoupling essentialist expectations of performers from our evaluation of complex engagements across cultures (amongst so many other boundaries). I believe it means remembering that theatre insisted, long ago, that fiction can lead toward justice as unerringly as fact can.

NOTES

1 The MFA's description of La Japonaise is freely available on their website: www.mfa.org/collections/ object/la-japonaise-camille-monet-in-japanese-costume-33556, accessed 12 July 2018. For other critics describing La Japonaise see Mary Mathews Gedo, Monet and His Muse: Camille Monet in the Artist's Life (Chicago: The University of Chicago Press, 2010). Lionel Lambourne, Japonisme: Cultural Crossings between Japan and the West (London: Phaidon, 2005), p. 111.

3 As of the time of going to press, both the MFA's official publicity images of the replica kimono and numerous photographs of the protesters were freely available on the Internet, including the MFA's Facebook event for Kimono Wednesdays at www.facebook.com/mfaboston/photos/a.157948467320. 125412.28314922320/10152912478132321/?type=3\&theater, accessed 12 July 2018, and Decolonize Our Museums' Tumblr page at https://decolonizeourmuseums.tumblr.com/post/163989773029/archiveprotest-against-kimono-wednesdays-at, accessed 12 July 2018. Malcolm Gay, 'MFA Recasts Kimono Days after Complaints of Stereotyping', Boston Globe, 7 July 2015. n.p.

5 Japanese nouns do not have plural forms. One kimono is a kimono; two are two kimono.

6 Hyperallergic, 'The Confused Thinking behind the Kimono Protests at the Boston Museum of Fine Arts', at https://hyperallergic.com/223047/the-confused-thinking-behind-the-kimono-protests-at-the-bostonmuseum-of-fine-arts/, accessed 16 January 2018.

7 'Decolonize Our Museums', Tumblr.com, at https://decolonizeourmuseums.tumblr.com/image/ 125342654564, accessed 10 July 2018.

8 Stephanie McFeeters, 'Counter-protesters Join Kimono Fray at MFA', Boston Globe, 19 July 2015. n.p.

9 Shaun O’Dwyer, 'Of Kimono and Cultural Appropriation', Japan Times, 4 August 2015, at www. japantimes.co.jp/opinion/2015/08/o4/commentary/japan-commentary/kimono-cultural-appropriation, accessed 16 January 2018.

10 'FAQ Made of Our Concerns', Decolonize Our Museums, at https://decolonizeourmuseums.tumblr. com/post/125347896294/faq-made-of-our-concerns, accessed 10 July 2018.

11 Kei Hiruta, 'Stop Orientalism?', at http://blog.practicalethics.ox.ac.uk/2015/o7/stop-orientalism-onboston-mfas-kimono-wednesdays, accessed 17 April 2017, reprinted in David Edmonds, ed., Philosophers Take on the World (Oxford: Oxford University Press, 2016), pp. 164-7. Italics in the original. Minh-Ha T. Pham, 'Fashion's Cultural-Appropriation Debate: Pointless', The Atlantic, 15 May 2014. n.p.

13 Robin Bernstein, 'Dances with Things: Material Culture and the Performance of Race', Social Text, 27, 4 (2009), pp. 67-94, here p. 69.

14 For example, James Tissot's La Japonaise au bain (1864), Alfred Wordsworth Thompson's La Japonaise, Léon François Comerre's La Japonaise (n.d.), Émile Villa's La Japonaise (1878?) and James Whistler's The Princess from the Land of Porcelain (1863-4). 
Liza Crihfield Dalby, Kimono: Fashioning Culture (Seattle: University of Washington Press, 2001), p. 65. Ibid., p. 67.

Ibid., p. 9.

Michelle Liu Carriger, Theatricality of the Closet (PhD dissertation, Brown University, 2013), pp. 129-67. For more on salvage anthropology see, for example, Barbara Kirshenblatt-Gimblett, Destination Culture (Berkeley: University of California Press, 1998).

There would be much more to say about contemporary Japanese campaigns to 'save' or 'revive' kimono for the present. There is a subset of Japan's robust magazine market dedicated to kimono fashions and how-to periodicals, from which sprang a sub-subset of vintage kimono styling, often attributed to a single title: Kimono Hime ('Kimono Princess') which, since 2002, has provided an alternative aesthetic of vintage, fashionable kimono primarily aimed at young women. Additional titles and one-off publications provide guidance and encouragement for young women to find occasions to wear kimono. While a kimono-outing club called Kimono de Jack (which boasts individually organized chapters around the world) and other groups exist to promote quotidian kimono wear, in general this is a trend that lives most vibrantly in the pages of magazines. One exception to this is the burgeoning kimono rental studios, especially in Kyoto and other tourist destinations, which cater to Japanese and foreign tourists who want to get dressed up to stroll around Gion or other traditional locales.

1 It is a widely accepted (if not uncriticized) tenet of Japanese studies that 'domestication' of foreign influences is a fundamental dynamic of Japanese culture. For a typical example see Joseph J. Tobin, Re-made in Japan: Everyday Life and Consumer Taste in a Changing Society (New Haven, CT: Yale University Press, 1992). For an important critique of the essentialist underpinnings of these ideas (widely shared by both Japanese and non-Japanese scholars) see Koichi Iwabuchi, Recentering Globalization: Popular Culture and Japanese Transnationalism (Durham, NC: Duke University Press, 2002).

See, for example, the seventeenth-century screen painting of Okuni held by the Tokugawa Art Museum. Or Terry Satsuki Milhaupt, Kimono: A Modern History (London: Reaktion Books, 2014), p. 38.

The sakoku period of Japanese isolation is frequently mischaracterized as total seclusion from the rest of the world, while in fact Japan maintained heavily controlled, tightly limited trade relations with China and the Netherlands throughout that period, which naturally also involved some cultural exchange and scholarship. The change from sakoku to Matthew Perry's 'opening' of the country and the Meiji government's policy of internationalization is a change in scale and degree, not a complete about-face. For claims about the complication of Western womenswear see, for example, Julia Meech-Pekarik, The World of the Meiji Print (New York: Weatherhill, 1986), pp. 130-1.

4 Interestingly, when I posted this image on social media, one of my Facebook friends, a former State Department officer in Japan (among other countries), wondered pointedly how the Americans in attendance reacted to this presentation. Clara Whitney, for one, loved it, but my friend seemed to think it could be offensive to recast the US flag as a geisha costume - precisely, and conveniently, inversely sensitive to what the kimono protesters were concerned about at the MFA. Quoted in Meech-Pekarik, The World of the Meiji Print, p. 110.

Rie Mori, 'Kimono and Colony: From Testimonies and Literatures', Voices from Japan, 25 (March 2011), pp. 17-20, here p. 18.

In addition to Edward Said's canonical work Orientalism, see, for example, Rey Chow, The Protestant Ethnic and the Spirit of Capitalism (New York: Columbia University Press, 2003), p. 107.

Gedo, Monet and His Muse, p. 174.

It is further worth noting how many Japonist paintings feature seemingly non-Japanese women wearing kimono, and how many of those paintings' titles nevertheless claim, like La Japonaise, 'Japanese girl', 'Japanese woman' and so on in the title, as if there were some performative property of the kimono itself to make its wearer Japanese for artistic purposes.

Gedo, Monet and His Muse, p. 174. 
31 Kāpena, Facebook comment, 19 June 2015, at www.facebook.com/mfaboston/photos/a.157948467320. 125412.28314922320/10152912478132321, accessed 10 July 2018.

32 McFeeters, 'Counter-protesters Join Kimono Fray', capitalization in original.

33 Capitalization and spelling in original.

34 For example, Cathy Young, "The Totalitarian Doctrine of "Social Justice Warriors"', The Observer, 2 February 2016. n.p.

35 Malcolm Gay, 'Kimono Controversy Erupts Anew at MFA Panel', Boston Globe, 8 Feb 2016, at www.bostonglobe.com/arts/2016/o2/o8/kimono-controversy-erupts-anew-mfa-panel/ olduJEpYVqUUyTM3wunRUM/story.html, accessed 10 July 2018.

36 Keiko Kawabe, 'Part 2: Kimono Wednesdays Protest Postmortem: The Protesters', at http:// japaneseamericaninboston.blogspot.com/2015/o8/part-2-kimono-wednesdays-protest.html, accessed 10 July 2018.

37 O’Dwyer, 'Of Kimono and Cultural Appropriation'.

38 That Japanese Man Yuta, 'Can Foreigners Wear Kimono?', at www.youtube.com/watch? v=opXotxxYFlk, accessed 10 July 2018.

39 Representative reactions, beginning with references to the Utah geisha birthday: Casey Baseel, 'Japanese Tumblr User Drops Hammer on Debate of If Caucasian Girl's Japan-themed Party was Racist', at https:// soranews24.com/2017/08/o8/japanese-tumblr-user-drops-hammer-on-debate-of-if-caucasian-girlsjapan-themed-party-was-racist, accessed 10 July 2018. Gavin J. Blair, 'Japanese Fans React to "Ghost in the Shell”', at www.hollywoodreporter.com/heat-vision/japanese-fans-react-ghost-shell-992255, accessed 10 July 2018. Isabelle Khoo, 'Mom Called Racist for Throwing Daughter a Japanese-Themed Birthday', at www.huffingtonpost.ca/2017/08/02/japanese-birthday-party_a_23061529/, accessed 10 July 2018. Casey Baseel, 'Japanese Twitter Seems to Have No Problems with Karlie Kloss' "Geisha” Photo Shoot', at https://soranews24.com/2017/02/17/japanese-twitter-seems-to-have-no-problems-with-karliekloss-geisha-photo-shoot, accessed 10 July 2018.

40 The first season of Unbreakable Kimmy Schmidt attracted its own variety of DOM-like criticism of the character Jacqueline, a blonde-haired, blue-contact-wearing socialite who turns out to be a Native American raised on a South Dakota reservation who has been hiding her non-white heritage.

41 My reasoning here is indebted to Tavia Nyong'o. In The Amalgamation Waltz (University of Minnesota Press, 2009), p. 136, he writes, 'I am preoccupied not with the virtues of getting it right but with the ethical chance that may lie within getting it wrong. What does it mean to mistake a memory, to remember by mistake, or even to remember a mistake?'

42 Keiko Kawabe, 'Part 1: Kimono Wednesdays Protest Postmortem: Media, Public, Critics', Japanese-American in Boston, at http://japaneseamericaninboston.blogspot.com/2015/o8/part-1kimono-wednesdays-protest.html, accessed 10 July 2018.

43 Judith Butler, 'Performative Acts and Gender Constitution', Theatre Journal, 40, 4 (December 1988), pp. 519-31, here p. 520.

MICHELLE LIU CARRIGeR (carriger@ucla.edu) is an Assistant Professor in the Theater Department at UCLA, where her research interests include performance and historiography, particularly in conjunction with queer, feminist, critical race and transnational theories. Her current book project examines clothing controversies and quotidian performances of self in nineteenth-century Britain and Japan, as well as historically inflected fashions in contemporary subcultures. Her first excerpt from this work, "The Unnatural History and Petticoat Mystery of Boulton and Park": A Victorian Sex Scandal and the Theatre Defense', appeared in TDR and won the Gerald Kahan award from the American Society for Theatre Research in 2014. She is the Focus Group Representative for the Performance Studies Focus Group of the Association for Theatre in Higher Education. 